\title{
Rola rodziny w procesie wychowania na przykładzie rodziny Jana Pawła II. W stulecie jego urodzin
}

Zagadnienie wychowania zajmuje ważne miejsce w nauczaniu papieża Jana Pawła II. Tematykę tę ojciec święty podejmował w wielu tekstach i wystąpieniach. Można powiedzieć, że pierwszym źródłem nauczania papieża był model wychowania, które zapewniła mu jego własna rodzina. Karol Wojtyła przyszedł na świat w stosunkowo biednej rodzinie, w czasie przełomowym dla dziejów Polski, kiedy to dokonywały się poważne przeobrażenia polityczne i społeczne, przerwane bolesną w skutkach drugą wojną światową. Ważnymi zdarzeniami w historii duchowego dojrzewania chłopca były głęboko przeżyte śmierci najbliższych: matki i brata. Poznanie rodziny św. Jana Pawła II potwierdzi, że gdyby papież nie nosił w sercu wartości, które w niej otrzymał, całe jego przesłanie i świętość mogłyby mieć inny wymiar.

Nic dziwnego, że temat wychowania towarzyszy mu podczas blisko dwudziestosiedmioletniego pontyfikatu i znajduje swoje znaczące miejsce w licznych dokumentach papieskich. Wspomnieć tu warto choćby adhortację apostolską Familiaris consortio (1983) czy List apostolski do rodzin „Gratissimam sane” z okazji Międzynarodowego Roku Rodziny (1994), a także 
wiele późniejszych wystąpień ojca świętego. Zapewne dzięki temu papież Jan Paweł II zasłużył sobie na miano patrona rodziny.

Warto więc spojrzeć na rolę i istotę wychowania człowieka w rodzinie w ujęciu polskiego papieża, a także na znaczący wpływ rodziny Jana Pawła II na jego wychowanie. Obok rodziny w procesie wychowania mają do spełnienia swoją rolę także inne instytucje, takie jak parafia i szkoła, dlatego warto przeanalizować ich znaczenie w wychowaniu przyszłego ojca świętego.

\section{Rola rodziny w wychowaniu}

Rodzina jest podstawowym środowiskiem życia każdego człowieka, wywierającym zasadniczy wpływ na jego rozwój; jest pierwszą formą życia społecznego. Kształtuje się ona jako wspólnota ludzi skupiona na człowieku, jedynym i niepowtarzalnym: mężu, żonie, ojcu, matce, synu, córce. Dzieci są konkretnym owocem miłości ślubowanej przy ołtarzu. Rodzina oparta jest na małżeństwie, w którym wzajemny dar z siebie samego mężczyzny i kobiety stwarza takie środowisko życia, w którym dziecko może się urodzić, rozwijać swe możliwości, nabywać świadomość własnej godności i przygotowywać się do wypełnienia swojego zadania ${ }^{1}$.

Do podstawowych zadań każdej rodziny należy wychowywanie potomstwa, dlatego też ojcostwo i macierzyństwo nie kończą się z chwilą narodzin dziecka. Proces wychowawczy w łonie wspólnoty rodzinnej polega przede wszystkim na umiejętności wzajemnego obdarzania się człowieczeństwem. Jest on dwustronny - rodzice obdarzają swym dojrzałym człowieczeństwem nowo narodzonego człowieka, ten zaś daje im całą swą nowość i świeżość, które przynosi ze sobą na świat ${ }^{2}$. Rzetelne wychowanie musi odwoływać się do wartości trwałych, takich jak poszanowanie godności osoby, uczciwość, odpowiedzialność i solidarność międzyludzka. W innym przypadku młodzi ludzie skazani są na moralne zagubienie, tracą poczucie bezpieczeństwa i stają się podatni na wszelkie rodzaje manipulacji płynącej z otoczenia ${ }^{3}$.

Jan Paweł II, Encyklika Centesimus annus, 39.

Jan Paweł II, List do Rodzin w 1994 z okazji Międzynarodowego Roku Rodziny, 16.

M. Gogacz, Podstawy wychowania, Niepokalanów 1993, s. 13. 
Wychowanie to „świadomie organizowana działalność społeczna oparta na relacji między wychowawcą a wychowankiem, której celem jest wywołanie zamierzonych zmian w osobowości wychowanka. Zmiany te obejmują zarówno stronę poznawczo-instrumentalną związaną z poznawaniem rzeczywistości i umiejętnością oddziaływania na nią, jak i stronę emocjonalno-motywacyjną, która polega na kształtowaniu stosunku człowieka do świata i ludzi, jego przekonań i postaw, układu wartości i celu życia”4.

W swej istocie wychowanie oznacza kształtowanie osobowości ludzkiej. Winno ono prowadzić do rozwoju fizycznego, intelektualnego, uczuciowego i moralnego. Zadaniem rodziny jest jednak zwrócenie szczególnej uwagi na wychowanie moralne, społeczne i religijne. Moralność można określić jako postępowanie zgodne z przyjętymi normami i zasadami etycznymi, które kształtują styl życia indywidualnego, oraz regulują stosunki międzyludzkie. U jej podstaw znajdują się pojęcia dobra i zła. Każdy świadomy czyn ludzki, jeśli jest zgodny z obiektywnymi zasadami etycznymi, jest dobry pod względem moralnym, a w przypadku niezgodności z normami moralnymi jest czynem złym ${ }^{5}$.

Wychowanie winno być procesem dwustronnej relacji obdarowującej „mistrz-uczeń”. Musi się ona opierać na wartościach trwałych, takich jak poszanowanie godności osoby, uczciwość, odpowiedzialność, solidarność wobec innych. Jan Paweł II wyraźnie zaznaczał, że wychowanie bez systemu wartości opartego na prawdzie oznacza skazanie młodych ludzi na moralne zagubienie, odebranie im poczucia bezpieczeństwa i uczynienie ich podatnymi na manipulację. Istotę i sens wychowania najlepiej wyrażają słowa papieża, które wygłosił w siedzibie UNESCO 2 czerwca 1980 roku: „W wychowaniu chodzi właśnie o to, ażeby człowiek stawał się coraz bardziej człowiekiem; o to, ażeby bardziej był, a nie tylko więcej miał; aby więc poprzez wszystko, co ma, co posiada, umiał bardziej i pełniej być człowiekiem, to znaczy ażeby również umiał bardziej być nie tylko z drugimi, ale i dla drugich"6.

$\mathrm{W}$ procesie zapoznawania się $\mathrm{z}$ normami postępowania moralnego istotną rolę odgrywają rodzice, którzy oddziałują na dziecko całym swoim

\footnotetext{
$4 \quad$ L. Zarzecki, Teoretyczne podstawy wychowania. Teoria i praktyka w zarysie, Warszawa 2012 , s. 4 .

5 T. Borutka, Nauczanie społeczne papieża Jana Pawła II, Kraków 1994, s. 142.

6 Jan Paweł II, W imię przyszłości kultury, „L’Osservatore Romano” (wyd. pol.) 1 (1980) nr 6, s. 5 .
} 
zachowaniem i postępowaniem. $\mathrm{Z}$ tego też powodu wychowanie moralne $\mathrm{w}$ rodzinie nie może się ograniczać do samych werbalnych nakazów i zakazów, lecz wymaga żywego, osobistego przykładu ze strony rodziców. Zasadniczą sprawą $\mathrm{w}$ wychowaniu moralnym jest prawidłowe kształtowanie sumienia. Łączy się z tym dojrzewanie do korzystania z wolności i do ponoszenia odpowiedzialności za swe czyny i życie ${ }^{7}$.

W kształtowaniu osobowości ważną rolę spełnia również wychowanie społeczne. W rodzinie rodzą się przecież obywatele i w to niej znajdują pierwszą szkołę cnót społecznych, które stanowią o życiu i rozwoju społeczeństwa ${ }^{8}$. Rodzina jest więc jedyną i niezastąpioną wartością dla rozwoju społeczeństwa. Jan Paweł II uważa ją za wspólnotę podstawową w najszerszym tego słowa znaczeniu, gdyż posiada ona „potężne energie, które są zdolne wyrwać człowieka $\mathrm{z}$ anonimowości, podtrzymać w nim świadomość godności własnej osoby, wzbogacać go głęboko człowieczeństwem i włączyć, zachowując jego odrębność i niepowtarzalność, w tkankę społeczeństwa"

\section{Rodzice Jana Pawła II}

Nie ulega najmniejszej wątpliwości, że duchowa postawa przyszłego papieża i świętego uformowała się w rodzinie dzięki wierze jego rodziców. Zanim wyruszył w świat, jako uczony i pasterz, zanim zasiadł na tronie Piotrowym, wpierw był synem i bratem konkretnych ludzi. Był także aktywnym członkiem swojej rodzinnej parafii i środowiska szkolnego; w nich wzrastał do człowieczeństwa i przygotowywał się do wypełniania społecznej misji, która $\mathrm{z}$ każdym kolejnym rokiem ukazywała mu nowe wyzwania, coraz większe i bardziej odpowiedzialne.

Podczas kolejnej pielgrzymki do Ojczyzny, 22 maja 1995 roku w Bielsku-Białej, Jan Paweł II przypomniał: „Z waszym miastem związany byłem od wczesnego dzieciństwa, gdyż w Bielsku-Białej urodził się mój ojciec, tutaj w okolicy mieszkali moi krewni, a w bielskim szpitalu pracował mój starszy brat - lekarz - i tam też zmarł, służąc chorym. Potem doszły związki innego

\footnotetext{
Jan Paweł II, Adhortacja apostolska Familiaris consortio, 36. Jan Paweł II, List do Rodzin, 42. Jan Paweł II, Adhortacja apostolska Familiaris consortio, 43.
} 
rodzaju, wynikające z mojej posługi biskupiej"10. Istotnie, ojciec papieża, Karol Wojtyła, syn Macieja i Anny, urodził się 18 lipca 1879 roku we wsi Lipnik k. Białej. Idąc w ślady ojca, Karol Wojtyła senior miał zostać krawcem, ale w wieku dwudziestu jeden lat został powołany do wojska austriackiego i już do końca życia pozostał zawodowym wojskowym. Ojciec Jana Pawła II był człowiekiem głęboko religijnym i jako taki wywarł wielki wpływ na osobowość późniejszego papieża, ukształtował także jego życie duchowe. Ukończył pięć klas niemieckiej szkoły ludowej, a w 1890 roku rozpoczął naukę w niemieckim gimnazjum państwowym w Bielsku. Jako czternastolatek musiał przerwać edukację, by pracować w zakładzie krawieckim ojca.

Powołany w październiku 1900 roku do wojska, gdyż mieszkał na terenie zaboru austriackiego, gdzie mężczyźni mieli obowiązek służby wojskowej w cesarsko-królewskiej armii, zdecydował się na służbę zawodową. Przez trzy lata (1901-1903) służył we Lwowie, później jako podoficer sztabowy został przeniesiony do Krakowa i tam poznał Emilię Kaczorowską, z którą zawarł ślub w kościele garnizonowym pw. św. Piotra i Pawła w Krakowie 10 lutego 1906 roku $^{11}$. Młodzi zamieszkali w Krakowie, gdzie przebywali aż do 1919 roku. Gdy Karol Wojtyła senior otrzymał przydział do 56 Pułku Piechoty, tzw. wadowickiego, rodzina z synem Edmundem wynajęła mieszkanie w kamienicy w Wadowicach. Wojtyłowie mieszkali tam do 1938 roku. W sypialni tego mieszkania 18 maja 1920 roku przyszedł na świat Karol Wojtyła.

W Boże Narodzenie 1940 roku w Krakowie Karol Wojtyła senior poważnie zachorował. Zmarł na niewydolność serca 18 lutego 1941 roku. To nagłe odejście wstrząsnęło synem, który żałował, że nie było go przy umierającym ojcu. Po latach, w 1994 roku, podczas prywatnej rozmowy w Rzymie ze swym przyjacielem z czasów krakowskich, Juliuszem Kydryńskim, ojciec święty wspomniał to zdarzenie: „Nigdy nie czułem się tak samotny”"2. Pogrzeb Karola Wojtyła seniora odbył się 22 lutego 1941 roku na Cmentarzu Rakowickim w Krakowie ${ }^{13}$.

\footnotetext{
10 Jan Paweł II, Trzeba otwierać drzwi Chrystusowi, „L’Osservatore Romano” (wyd. pol.) 16 (1995) nr 7 (175), s. 31-32.

11 T. Borutka, W życiu i śmierci „Totus Tuus”. Sylwetka duchowa, działalność pastoralna i dorobek intelektualny papieża Jana Pawła II, Kraków 2010, s. 16-17.

12 T. Borutka, W życiu i śmierci „Totus Tuus”, dz. cyt., s. 18.

13 T. Borutka, W życiu i śmierci „Totus Tuus”, dz. cyt., s. 18.
} 
Emilia Anna Kaczorowska, matka późniejszego papieża, urodziła się 26 marca 1884 roku w Krakowie ${ }^{14}$. Rozpoczęła naukę w 1890 roku. W Spisie ludności miasta Krakowa z tego roku w rodzinie Feliksa Kaczorowskiego przy jej imieniu podano, że jest uczennicą klasy pierwszej szkoły normalnej. W wieku sześciu lat zaczęła zatem naukę w tzw. szkole głównej - najlepszej ze szkół podstawowych, określanych wtedy ludowymi, pospolitymi czy powszechnymi. Przyszła matka papieża zdobyła zatem gruntowne wykształcenie i przygotowanie do życia ${ }^{15}$. Jako trzynastoletnia dziewczynka Emilia doświadczyła dramatu śmierci swojej matki Marii Kaczorowskiej, która wcześniej długo chorowała.

Emilia zmarła 13 kwietnia 1929 roku w wieku czterdziestu pięciu lat. W księdze zmarłych parafii Ofiarowania Najświętszej Maryi Panny w Wadowicach odnotowano przyczynę jej zgonu: myocarditis nephritis, czyli zapalenie mięśnia sercowego i nerek. W pogrzebie, który 16 kwietnia 1929 roku prowadził ks. Leonard Prochownik, uczestniczył mąż Karol ze swymi dwoma synami. Po uroczystościach żałobnych cała rodzina udała się na pielgrzymkę do sanktuarium maryjnego w Kalwarii Zebrzydowskiej ${ }^{16}$.

\section{Rodzeństwo Jana Pawła II}

Edmund Antoni Wojtyła, starszy brat Karola, przyszedł na świat w 1906 roku w Krowodrzy (później dzielnicy Krakowa) jako pierworodny syn Emilii i Karola Wojtyłów. Dokładna data urodzenia nie jest pewna; dzień 28 sierpnia pojawia się w aktach wojskowych archiwum wiedeńskiego, zaś 27 sierpnia - na tablicy nagrobnej i w akcie zgonu ${ }^{17}$. Od 1913 roku uczył się w Powszechnej Szkole im. Stanisława Jachowicza w Wadowicach. Zachowała się cenzurka młodego Wojtyły; oprócz „chwalebnego zachowania” zwracają uwagę bardzo dobre stopnie z religii, czytania, pisania, języka polskiego i języka niemieckiego oraz śpiewu i rysunku.

\footnotetext{
14 M. Kindziuk, Matka Papieża. Poruszająca opowieść o Emilii Wojtyłowej, Kraków 2013.

T. Borutka, W życiu i śmierci „Totus Tuus”, dz. cyt.

T. Borutka, W życiu i śmierci „Totus Tuus”, dz. cyt., s. 20.

T. Borutka, W życiu i śmierci „Totus Tuus”, dz. cyt., s. 21.
} 
W dokumentach szkolnych znajdujemy także informację mówiącą, iż 10 listopada 1914 roku Edmund, uczeń klasy III szkoły im. Stanisława Jachowicza, „przesiedlił się z rodzicami do Mähr. Weisskirchen” (obecnie czeskie Hranice na Morawach). Przenosiny były spowodowane przekwaterowaniem garnizonu 56 Pułku Piechoty, w którym służył jego ojciec. Tam starszy syn Wojtyłów skończył szkołę powszechną i kontynuował naukę w Niższym Wojskowym Gimnazjum Realnym.

Gdy w 1918 roku kończyła się wojna, rodzina powróciła do Wadowic i zajęła mieszkanie nr 2 przy Rynku (dziś ul. Kościelna 7). W tymże 1918 roku Edmund rozpoczął kolejny etap edukacji w III klasie Państwowego Gimnazjum im. Marcina Wadowity. Jego nazwisko znajduje się na liście uczniów w sprawozdaniach dyrekcji gimnazjum z lat 1918/19 i 1920/21. Maturę zdał z wyróżnieniem 12 czerwca 1924 roku. Podobnie jak młodszy o czternaście lat brat Karol, Edmund cenił teatr i występował w amatorskim zespole prowadzonym przez Mieczysława Kotlarczyka.

W tym samym roku rozpoczął sześcioletnie studia na Wydziale Lekarskim Uniwersytetu Jagiellońskiego w Krakowie ${ }^{18}$, które ukończył 28 maja 1930 roku z wyróżnieniem magna cum laude, uzyskując tytuł doktora wszech nauk lekarskich (łac. doctoris medicinae universae). W uroczystości wręczenia dyplomów uczestniczyli ojciec i brat Karol, który po pięćdziesięciu latach od tego wydarzenia wspominał: „Pierwszy raz wszedłem w mury Collegium Maius jako dziesięcioletni uczeń szkoły powszechnej, aby uczestniczyć w promocji doktorskiej mojego starszego brata, absolwenta Wydziału Lekarskiego UJ. Do dzisiaj mam w oczach tę uroczystość w auli uniwersyteckiej"19.

Po studiach i otrzymaniu dyplomu Edmund odbył kilkumiesięczną praktykę w Szpitalu Dziecięcym im. św. Ludwika w Krakowie, gdyż pragnął poświęcić się leczeniu dzieci. Pracę zawodową rozpoczął 1 kwietnia 1931 roku w Bielsku, głównym mieście Podbeskidzia (dzisiaj Bielsko-Biała). Wojtyła objął stanowisko zastępcy ordynatora Oddziału Zakaźnego w Powszechnym Szpitalu Miejskim w Bielsku.

18 T. Borutka, W życiu i śmierci „Totus Tuus”, dz. cyt., s. 23.

19 Jan Paweł II, Niech obecność twoja w życiu Polski służy zwycięstwu tego, co godne człowieka. Przemówienie na Uniwersytecie Jagiellońskim, „L’Osservatore Romano” (wyd. pol.) 4 (1983) nr nadzwyczajny, I, s. 11. 
Od wczesnej jesieni 1932 roku w Bielsku, Białej i okolicy panowała epidemia płonicy, czyli szkarlatyny. W tym właśnie czasie do szpitala w Bielsku przywieziono w stanie śpiączki pacjentkę, dwudziestojednoletnią kobietę. Trafiła na oddział doktora Wojtyły, który zalecił pozostanie w szpitalu, zaaplikował leczenie, za wszelką cenę starając się uratować jej życie. Kiedy jednak zakażenie nie ustępowało, a choroba roznosiła się po całym organizmie, powodując powikłania, personel medyczny szpitala opuścił pacjentkę. Lekarze i pielęgniarki w obawie, że sami zarażą się szkarlatyną, nie wchodzili nawet do izolatki, w której leżała. Wtedy leczenia podjął się osobiście doktor Edmund Wojtyła. Narażając własne życie, czuwał przy niej w izolatce zarówno w dzień, jak i w nocy. Niestety, nie zdołał uratować chorej.

Walcząc o życie pacjentki, sam zaraził się płonicą. Jego organizm źle znosił chorobę, bardzo cierpiał. Stan doktora opisywano tak: „Ciało pokryły czerwone plamy. Miał straszne bóle głowy. Temperatura - ponad czterdzieści stopni. Męczyły go napady drgawek. Zachorował, ponieważ zbyt krótko pracował na oddziale zakaźnym i nie zdążył się uodpornić... Agonia trwała cztery dni”20. Umarł 4 grudnia 1932 roku w wieku 26 lat.

Po siedemdziesięciu latach od tych smutnych zdarzeń, 1 grudnia 2002 roku, z okazji nadania imienia Edmunda Wojtyły Szpitalowi Ogólnemu w Bielsku-Białej, ojciec święty Jan Paweł II napisał: „Nie było dane Edmundowi długo pracować w tym szpitalu. Wiem jednak, że głęboko był z nim związany, a swoją pracę wśród chorych traktował bardzo poważnie. Miałem takie odczucie, gdy odwiedzałem go w tym szpitalu i gdy o tym rozmawialiśmy. W duchu lekarskiej powinności towarzyszył cierpiącym wtedy, gdy ówczesny stan medycyny nie dawał już możliwości skutecznej pomocy. A potem on sam doświadczył śmiertelnej choroby. Jego przedwczesne odejście zapisało się głęboko w moim sercu, ale nie tylko w moim, skoro pamięć o jego samarytańskiej postawie zachowała się aż dotąd. Po siedemdziesięciu latach od jego śmierci wciąż wspominam go z braterską miłością i polecam jego duszę miłosiernemu Bogu"21.

20 M. Kindziuk, Dzisiejsi medycy sa jak doktor Edmund Wojtyła, brat Jana Pawła II, www.wpolityce.pl/spoleczenstwo/491807-dzisiejsi-medycy-sa-jak-doktor-edmund-wojtyla-brat-jp-ii/ (09.04.2020).

21 Jan Paweł II, Podziękowanie za nadanie imienia Edmunda Wojtyły Szpitalowi Ogólnemu w Bielsku-Białej, w: Jan Paweł II, „Być człowiekiem sumienia”. Przemówienia wygłoszone podczas pielgrzymki do diecezji i inne teksty papieża, red. T. Borutka, Kraków 2007, t. IV, s. 231. 
Siostra Karola Wojtyła juniora, Olga Maria, urodziła się i zmarła tego samego dnia - 7 lipca 1916 roku w Białej. Dane te udokumentowane są w dwóch wiarygodnych źródłach, niezauważonych dotąd przez biografów papieskich. Żadne opracowanie o Janie Pawle II nie podaje jej daty urodzin i śmierci. Papież wspomniał ją jednak w swym testamencie na równi $\mathrm{z}$ rodzicami i bratem. Po raz pierwszy dowiedzieliśmy się o starszej siostrze Jana Pawła II z publikacji André Frossarda ${ }^{22}$. W dotychczasowych opracowaniach o Janie Pawle II jako datę urodzin i śmierci jego siostry podawano rok 1914, a jako miejsce urodzenia - Kraków.

Fakt ten ustalił ponad wszelką wątpliwość dziennikarz Katolickiej Agencji Informacyjnej, Grzegorz Polak, popularyzator nauczania Jana Pawła II. Do odkrycia doszło podczas rutynowych prac zespołu scenariuszowego Muzeum Jana Pawła II i Prymasa Wyszyńskiego powstającego przy Centrum Opatrzności Bożej w Warszawie, który tworzą dr Paweł Skibiński, dyrektor placówki, Janusz Kotański oraz Grzegorz Polak ${ }^{23}$.

Fakt ten potwierdza zapis w Liber mortuorum (księdze zmarłych) znajdującej się w parafii pw. Opatrzności Bożej w Bielsku-Białej (dawna Biała), rodzinnej parafii ojca Karola Wojtyły. Pod datą 7 lipca 1916 roku widnieje notatka, że tego dnia zmarła Olga Maria Wojtyła, córka Karola i Emilii. Siostra papieża żyła zaledwie szesnaście godzin. Pogrzeb dziewczynki odbył się dwa dni później, 9 lipca, jednak w dokumentach parafialnych nie ma żadnych śladów stwierdzających, że została pochowana na bialskim cmentarzu, gdzie spoczywają dziadkowie papieża ze strony ojca.

\section{Wpływ rodziny na wychowanie}

Doceniając znaczenie samowychowania człowieka, należy zauważyć, że decydujący wpływ na rozwój osoby ludzkiej ma właśnie rodzina. To ona kształtuje charakter dziecka i uczy je właściwego stosunku do otoczenia, a dalej do swojej małej i wielkiej ojczyzny oraz do wspólnoty Kościoła, z którą dana

22 A. Frossard, „Nie lękajcie się!” Rozmowy z Janem Pawłem II, tłum. A. Turowiczowa, Rzym 1982, s. 15.

23 Dziennikarz KAI odkrył fakty dotyczące siostry Jana Pawła II, www.ekai.pl/dziennikarz-kai-odkryl-fakty-dotyczace-siostry-jana-pawla-ii/ (09.04.2020). 
osoba czuje się od samego początku mniej lub bardziej zintegrowana. Zastanawiając się więc nad wyjątkowością św. Jana Pawła II, nad jego świętością, nie sposób nie dotrzeć do rodziny, do jego rodziców i rodzeństwa, którzy stali się dla niego pierwszą szkołą człowieczeństwa i świętości. Bez rodziny przyszły papież nie zdobyłby tej wielkiej mądrości życia.

„Po synowsku całuję próg domu rodzinnego, wyrażając wdzięczność Opatrzności Bożej za dar życia przekazany mi przez moich Rodziców, za ciepło rodzinnego gniazda, za miłość moich najbliższych, która dawała poczucie bezpieczeństwa i mocy, nawet wtedy, gdy przychodziło zetknąć się z doświadczeniem śmierci i trudami codziennego życia w niespokojnych czasach" - tak ojciec święty Jan Paweł II mówił na wadowickim rynku w czasie pielgrzymki do Ojczyzny w 1999 roku $^{24}$.

Papież przez cały pontyfikat przy różnych okazjach wyrażał publicznie wdzięczność swojej rodzinie, zachowywał ją w pamięci i w modlitwie. To rodzina ukształtowała jego system wartości i sposób myślenia, to od matki i ojca nauczył się wszystkiego, z czym poszedł w dorosłe życie. Można postawić tezę, że gdyby nie miłość i wychowanie rodziców, gdyby nie silne więzi rodzinne i tradycje kultywowane przez matkę i ojca, Karol Wojtyła nie byłby tym samym człowiekiem, być może nie byłby także tym samym księdzem, poetą, wreszcie papieżem.

Dom rodziny Wojtyłów jak większość domów w Polsce pielęgnował tradycję. W pierwszym okresie życia syna Karola trud jego wychowania spoczął na matce, gdyż ojciec pracował zawodowo. To ona ze względu na wychowanie dzieci zrezygnowała z pracy, by poświęcić im cały swój czas. Podczas trzeciej pielgrzymki do Polski (8-14 czerwca 1987 roku) Jan Paweł II ożywił swoje najwcześniejsze wspomnienia: „Ludzie często śpiewają papieżowi: «Niech żyje, niech żyje nam, niech żyje sto lat». Trudno wtedy nie pomyśleć [...] o mojej rodzonej Matce. Jeśli w ogóle żyję na świecie, to dlatego, że była ona, która mi to życie dała” ${ }^{25}$. „Ona chciała mieć dwóch synów - powie kiedy indziej - lekarza i księdza; mój brat był lekarzem, a ja mimo wszystko zostałem księdzem"26.

\footnotetext{
24 Jan Paweł II, Po synowsku caluje próg domu rodzinnego. Wadowice 16.06.1991, „L'Osservatore Romano” (wyd. pol.) 20 (1999) nr 8 (215), s. 113.

25 Jan Paweł II, Przed rozstaniem się z włókniarkami, „L'Osservatore Romano” (wyd. pol.) 8 (1987) nr 5 (90), s. 14.

26 A. Frossard, „Nie lękajcie się!”, dz. cyt., s. 14.
} 
Jak już wspomniano, Emilia Wojtyłowa tylko dorywczo wykonywała usługi krawieckie, pozostając w domu, by w ten sposób zaspokoić materialne potrzeby rodziny. Dbała także o intelektualny rozwój młodszego syna i wspomagała go w pierwszych latach szkolnych. Nie zapominała też o wychowaniu religijnym. Prowadziła syna wraz z mężem do pobliskiego kościoła oraz wspierała jego wysiłki, by został ministrantem. Cieszyła się jego postępami w nauce i dobrym zachowaniem w domu i poza nim. Była po matczynemu dumna ze swojego syna. Dbała też o jego wychowanie patriotyczne.

Niestety od chwili urodzenia Karola stopniowo podupadała na zdrowiu. Doświadczała różnych chorób i dotkliwych cierpień. Stan jej zdrowia pogorszył się znacząco w 1927 roku, a więc dwa lata przed śmiercią. Nie wychodziła wtedy z domu, niekiedy przebywała tylko na balkonie, gdzie lubiła szyć albo cerować ubrania synów. Potem już tylko leżała w łóżku. Przede wszystkim taki obraz matki zachował w pamięci Jana Pawła II. André Frossard zanotował: „Swoją matkę znał właściwie wyłącznie jako osobę chorą". Nic więc dziwnego, że papież powiedział później, iż „nauczył się cierpienia od matki"27.

Papież wspominał po latach: „Moje lata dziecięce i chłopięce zostały wnet naznaczone utratą osób najbliższych. Naprzód Matki, która nie doczekała dnia mojej Pierwszej Komunii Świętej"28. W jednej z przywoływanych tu rozmów z Frossardem wyznał także: „Matkę straciłem jeszcze [...] w wieku dziewięciu lat i dlatego mniej ją pamiętam. Po jej śmierci, a następnie po śmierci mojego starszego brata, zostaliśmy we dwójkę z Ojcem"29.

Śmierć Emilii spowodowała, że trud dalszego wychowania syna spoczął na ojcu, którego pogłębiona religijność silnie wpłynęła na osobowość młodego Karola Wojtyły, ukształtowała jego życie duchowe, zwłaszcza we wczesnym okresie życia. Papież o swoim ojcu powiedział: „Moje lata chłopięce i młodzieńcze łączą się przede wszystkim z postacią Ojca, którego życie duchowe po stracie żony i starszego syna niezwykle się pogłębiło. Patrzyłem $\mathrm{z}$ bliska na jego życie, widziałem, jak umiał od siebie wymagać, widziałem, jak klękał do modlitwy. To było najważniejsze w tych latach, które tak wiele znaczą w okresie dojrzewania młodego człowieka. Ojciec, który umiał sam

\footnotetext{
27 A. Frossard, „Nie lękajcie się!”, dz. cyt., s. 15.

28 A. Frossard, „Nie lękajcie się!”, dz. cyt., s. 15.

29 A. Frossard, „Nie lękajcie się!’, dz. cyt., s. 14.
} 
od siebie wymagać, w pewnym sensie nie musiał już wymagać od syna. $\mathrm{Pa}-$ trząc na niego, nauczyłem się, że trzeba samemu sobie stawać wymagania i przykładać się do spełniania własnych obowiązków. Ten mój Ojciec, którego uważam za niezłomnego człowieka, zmarł - prawie nagle - podczas drugiej wojny światowej i okupacji, zanim ukończyłem dwudziesty pierwszy rok życia"30.

Na kształtowanie się charakteru przyszłego papieża duży wpływ miał jego brat Edmund. Dla młodszego o czternaście lat Karola był mentorem i opiekunem, towarzyszem zabaw. Zabierał go na mecze piłkarskie i w góry. Dzięki Edmundowi Karol po raz pierwszy zobaczył Tatry. Jego kontakty $\mathrm{z}$ bratem były bardzo serdeczne, $\mathrm{z}$ biegiem lat potęgowały się, umacniały ich przyjaźń i więzy rodzinne. Nawet wtedy gdy Edmund pracował już w szpitalu w Bielsku, mały Karol z ojcem często go odwiedzali, nie unikając przy tym kontaktów z pacjentami bielskiego szpitala - wspominał kard. Stanisław Dziwisz w wywiadzie dla tygodnika „Niedziela” ${ }^{31}$. Nic więc dziwnego, że na biurku papieża w jego watykańskim apartamencie do końca pontyfikatu spoczywał stetoskop brata $\mathrm{z}$ bielskiego szpitala.

Niewątpliwie zaraz po rodzinie duże znaczenie w wychowaniu Karola miały środowiska parafialne i szkolne. „Kiedy patrzę wstecz, widzę, jak droga mojego życia, poprzez środowisko [...], poprzez parafię, poprzez moją rodzinę, prowadzi mnie do jednego miejsca: do chrzcielnicy w wadowickim kościele parafialnym. Przy tej chrzcielnicy zostałem przyjęty do łaski Bożego synostwa i do wiary Odkupiciela mojego, do wspólnoty Jego Kościoła, w dniu 20 czerwca 1920 roku”32. Nieco później papież powiedział: „A parafia wadowicka, która mnie zrodziła przez chrzest do życia Bożego, położyła temu mocne podwaliny: naprzód poprzez moich Rodziców i chrześcijańskie wychowanie rodzinne, następnie przez parafię, jej atmosferę, jej ducha, jej życie. [...] Patrzyłem tutaj na świetlane przykłady życia kapłańskiego, gorliwości kapłańskiej. Tak jak patrzyłem też na świetlane przykłady życia chrześcijańskiego moich wychowawców, profesorów,

\footnotetext{
30 A. Frossard, Nie lękajcie się, dz. cyt., s. 14.

31 S. Dziwisz, 85 lat temu w Bielsku zmarł Edmund Wojtyła, brat papieża, www.dzieje. pl/aktualnosci/85-lat-temu-w-bielsku-zmarl-edmund-wojtyla-brata-papieza (09.04.2020).

32 Jan Paweł II, Dziękuję z wami Bogu za każde dobro, które otrzymałem. W kościele parafialnym $w$ Wadowicach 7 czerwca 1979 roku, w: Jan Paweł II, Nauczanie papieskie, Poznań 1990, t.2/1, s. 681-682.
} 
moich rodaków starszego pokolenia, które jeszcze żyje, przynajmniej w pewnej części, i moich rówieśników"33.

W sposób szczególny ojciec święty Jan Paweł II wspominał ks. Kazimierza Figlewicza: „Ogromnie wiele zawdzięczam kapłanom, zwłaszcza jednemu [...]. W ciągu tych wszystkich lat moim spowiednikiem i bezpośrednim kierownikiem duchowym był ks. Kazimierz Figlewicz [...], który jeszcze $\mathrm{w}$ latach chłopięcych swoją ogromną prostotą i dobrocią przybliżał mi Chrystusa - a potem wiedział, w którym momencie mógł jako spowiednik powiedzieć mi: "Chrystus wskazuje ci drogę do kapłaństwa»"34.

W sercu Jana Pawła II pozostanie również rodzinne miasto; do końca będzie się czuł jego obywatelem, kimś „stąd” - i da tego liczne dowody, m.in. w takim wspomnieniu: „Wiadomo, jak wiele dla rozwoju ludzkiej osobowości i charakteru znaczą pierwsze lata życia, lata dziecięce, a potem młodzieńcze. Te właśnie lata łączą się dla mnie nierozerwalnie z Wadowicami, tym miastem, które nosiło wówczas dumny herb «Królewskie Wolne Miasto Wadowice»... A także i z tą okolicą. Z rzeką Skawą, z pasmami Beskidów”35.

Podczas ostatniego pobytu w Wadowicach (16 czerwca 1999 roku) papież wyznał przed rzeszą zgromadzonych: „To miasto lat dziecięcych [...] było świadkiem mych pierwszych kroków, pierwszych słów i tych - jak mówił Norwid - «pierwszych ukłonów», co są «jak odwieczne Chrystusa wyznanie: 'Bądź pochwalony!’». Miasto mego dzieciństwa, dom rodzinny, kościół parafialny, kościół mojego chrztu świętego. W tej świątyni przystąpiłem do spowiedzi i Pierwszej Komunii św. Tu byłem ministrantem. [...] A dom był [...] przy ulicy Kościelnej. A kiedy patrzyłem przez okno, widziałem na murze kościelnym zegar słoneczny i napis: «Czas ucieka, wieczność czeka». [...] Wiele wspomnień. W każdym razie tu, w tym mieście, w Wadowicach, wszystko się zaczęło, i szkoła się zaczęła, studia się zaczęły, i teatr się zaczął. I kapłaństwo się zaczęło"36.

Jan Paweł II wysoko ocenił swą szkołę, przez całe długie życie czuł się dłużnikiem nauczycieli i wychowawców, których wspominał wielokrotnie, zawsze w tonie najwyższego uznania. Nie zapominał o nich również

\footnotetext{
33 K. Wojtyła, Przemówienie z 4 listopada 1971 roku, w: Kazania i przemówienia kardynała Karola Wojtyły o kapłaństwie (1963-1978), red. J. Dyduch, Kraków 1995, s. 159.

34 A. Frossard, „Nie lękajcie się!”, dz. cyt., s. 20.

35 Jan Paweł II, Dziękuję z wami Bogu za każde dobro, które otrzymałem, dz. cyt., s. 681.

36 Jan Paweł II, Po synowsku całuję próg domu rodzinnego, dz. cyt., s. 115.
} 
w codziennej modlitwie. „To, co otrzymałem w latach szkolnych - powiedział - do dzisiaj owocuje w moim życiu" ${ }^{\text {"37. }}$

Z wielkimi nadziejami, ale też i z uznaniem, odnosił się do rozpoczętych w 1938 roku studiów polonistycznych na Uniwersytecie Jagiellońskim. „Później zrozumiałem, że te studia polonistyczne przygotowały we mnie grunt pod inny kierunek zainteresowań i studiów: mam na myśli filozofię i teologię"38. Wspomnienie tamtego czasu będzie mu towarzyszyć nieustannie: „Noszę głęboko zapisany w mojej pamięci ten jeden rok przedwojennych studiów: całe środowisko uniwersyteckie, nazwiska wielkich profesorów, których miałem szczęście być uczniem, twarze kolegów i koleżanek, z którymi w większości rozdzieliły mnie wydarzenia lat 1939-1945. Stąd pochodzi najwięcej moich kolegów i koleżanek, w tym samym czasie studiujących, albo na latach wyższych [...], albo też na moim roczniku. Chcę dodać, że na tym roczniku studiowało bardzo wielu czynnych literatów, poetów"39.

Karol Wojtyła był wdzięczny swej uczelni i tworzącym ją ludziom za ten rok niezapomnianych doświadczeń, za wiedzę i mądrość, którą mu dali. W słowach, jakie przywołał w jednym ze swoich wspomnień, latwo dostrzec emocjonalne - nawet po latach - zaangażowanie: „Uczelni Jagiellońskiej w Krakowie [...] zawdzięczam studia oraz pierwsze akademickie doświadczenia. Doświadczenia te wycisnęły w mojej świadomości oraz całej mojej osobowości głębokie ślady na całe życie. Może w sposób szczególny dlatego, że były one związane naprzód z okresem przed drugą wojną światową, z kolei - i to w większości - z okresem okupacji, wreszcie z pierwszymi latami okresu powojennego. Pamięć tego, czym jest Uniwersytet - Alma Mater - noszę w sobie wciąż żywą. Nie tylko pamięć, ale poczucie długu, który należy spłacać całym życiem. [...] Przez wiele lat jako krakowianin spotykałem się na co dzień z tym kompleksem gmachów, które kryją w sobie Uniwersytet - a jednak nie stracił on przez to nic ze swojej wielkości. Nie spowszedniał. [...] Stykając się z nim na co dzień w ciągu czterdziestu lat mojego tutaj pobytu, ani na chwilę nie straciłem tej świadomości, że obcuję

\footnotetext{
37 Jan Paweł II, Po synowsku całuję próg domu rodzinnego, dz. cyt., s. 115.

38 Jan Paweł II, Po synowsku całuję próg domu rodzinnego, dz. cyt., s. 115.

39 Jan Paweł II, Do profesorów uczelni Krakowa, w: Jan Paweł II, Nauczanie papieskie, dz. cyt., s. 692.
} 
z wielkością. Jedną z tych, które stanowią o miejscu mojej Ojczyzny w dziejach ogólnoludzkiej kultury" ${ }^{\prime 4}$.

\section{Podsumowanie}

Przyszłość każdego człowieka zależy od jego wychowania. Odpowiedzialni są za nie przede wszystkim rodzice, jest ono ich podstawowym prawem, ale też trudnym obowiązkiem. Mówiąc o wychowaniu, należy uwzględnić jego integralny charakter i mocno uwypuklić jego wymiar religijny.

Temat roli rodziny w wychowaniu człowieka był bliski Janowi Pawłowi II. Polski papież poświęcił mu w swoim nauczaniu sporo uwagi. Pisząc na ten temat, miał w świadomości swoją rodzinę: ojca Karola, matkę Emilię, starszego brata Edmunda i Olgę (Aleksandrę) - siostrę.

Choć cała rodzina miała znaczący wpływ na wychowanie przyszłego ojca świętego, to jednak najbardziej zaważył na nim ojciec, gdyż matka zmarła wcześnie, podobnie szybko odszedł starszy brat. To ojcu Karol junior najwięcej zawdzięczał; to ojciec miał największy udział w tym niełatwym procesie. Od niego młody Wojtyła uczył się człowieczeństwa i chrześcijańskiego postępowania. Ojciec był dla niego wzorem i niezwykłym oparciem.

Rzecz jasna, że po rodzinie niemałe znaczenie w wychowaniu przyszłego papieża miała jego rodzinna parafia w Wadowicach, zwłaszcza duszpasterze z ks. Kazimierzem Figlewiczem na czele oraz środowiska szkolne i uniwersyteckie. Ojciec święty Jan Paweł II wspominał te środowiska z wdzięcznością i prawdziwą dumą.

\section{Bibliografia}

Borutka T., Nauczanie społeczne papieża Jana Pawła II, Kraków 1994.

Borutka T., W życiu i śmierci „Totus Tuus”. Sylwetka duchowa, działalność pastoralna i dorobek intelektualny papieża Jana Pawła II, Kraków 2010.

40 Jan Paweł II, Jakie sa perspektywy tego pokolenia? (KUL 9 VI 1987), „L'Osservatore Romano" (wyd. pol.) 8 (1987) nr 5 (90), s. 11. 
Dziennikarz KAI odkrył fakty dotyczace siostry Jana Pawła II, www.ekai. pl/dziennikarz-kai-odkryl-fakty-dotyczace-siostry-jana-pawla-ii/ (09.04.2020).

Dziwisz S., 85 lat temu w Bielsku zmarł Edmund Wojtyła, brat papieża, www. dzieje.pl/aktualnosci/85-lat-temu-w-bielsku-zmarl-edmund-wojtyla-brata-papieza (09.04.2020).

Frossard A., „Nie lękajcie się!” Rozmowy z Janem Pawłem II, tłum. A. Turowiczowa, Rzym 1982.

Gogacz M., Podstawy wychowania, Niepokalanów 1993.

Jan Paweł II, Adhortacja apostolska Familiaris consortio o zadaniach rodziny chrześcijańskiej w świecie współczesnym, Watykan 1981.

Jan Paweł II, Dziękuję z wami Bogu za każde dobro, które otrzymałem. W kościele parafialnym $w$ Wadowicach 7 czerwca 1979 roku, w: Jan Paweł II, Nauczanie papieskie, Poznań 1990, t. 2/1, s. 681-682.

Jan Paweł II, Encyklika Centesimus annus w setną rocznicę encykliki „Rerum novarum", Watykan 1991.

Jan Paweł II, Jakie sa perspektywy tego pokolenia? (KUL 9 VI 1987), „L’Osservatore Romano” (wyd. pol.) 8 (1987) nr 5 (90), s. 11.

Jan Paweł II, List do Rodzin w 1994 z okazji Międzynarodowego Roku Rodziny, Watykan 1994.

Jan Paweł II, Niech obecność twoja w życiu Polski służy zwycięstwu tego, co godne człowieka. Przemówienie na Uniwersytecie Jagiellońskim, „L'Osservatore Romano” (wyd. pol.) 4 (1983) nr nadzwyczajny, I, s. 11.

Jan Paweł II, Po synowsku całujępróg domu rodzinnego, Wadowice 16.06.1991, „L'Osservatore Romano” (wyd. pol.) 20 (1999) nr 8 (215), s. 113-114.

Jan Paweł II, Podziękowanie za nadanie imienia Edmunda Wojtyły Szpitalowi Ogólnemu w Bielsku-Białej, w: Jan Paweł II, „Być człowiekiem sumienia”. Przemówienia wygłoszone podczas pielgrzymki do diecezji i inne teksty papieża, red. T. Borutka, Kraków 2007, t. IV, s. 231-232.

Jan Paweł II, Przed rozstaniem się z włókniarkami, „L’Osservatore Romano” (wyd. pol.) 8 (1987) nr 5 (90), s. 14.

Jan Paweł II, Trzeba otwierać drzwi Chrystusowi, „L'Osservatore Romano” (wyd. pol.) 16 (1995) nr 7 (175), s. 31-32.

Jan Paweł II, W imię przyszłości kultury, „L'Osservatore Romano” (wyd. pol.) 1 (1980) nr 6, s. 4-6. 
Kindziuk M., Dzisiejsi medycy sa jak doktor Edmund Wojtyła, brat Jana Pawła II, www.wpolityce.pl/spoleczenstwo/491807-dzisiejsi-medycy-sa-jak-doktor-edmund-wojtyla-brat-jp-ii/ (09.04.2020).

Kindziuk M., Matka Papieża. Poruszajaca opowieść o Emilii Wojtyłowej, Kraków 2013.

Wojtyła K., Przemówienie z 4 listopada 1971 roku, w: Kazania i przemówienia kardynała Karola Wojtyly o kapłaństwie (1963-1978), red. J. Dyduch, Kraków 1995.

Zarzecki L., Teoretyczne podstawy wychowania. Teoria i praktyka w zarysie, Warszawa 2012. 
